\title{
Urban Advantage? Sustainability Trade-Offs Across and Within the Intra-Urban Space
}

\author{
Lin Lerpold, Örjan Sjöberg, and Wing-Shing Tang
}

\section{INTRODUCTION}

As urbanisation is continuing a-pace, with emerging and low-income countries following in the footsteps of the mature industrialised economies, we need to understand urban consumption and production patterns as well as the sustainability impacts it implies. While a sizeable literature suggests that larger cities are more efficient, indeed also more

\section{Lerpold (凶)}

Center for Sustainability Research, Department of Marketing and Strategy, Stockholm School of Economics, Stockholm, Sweden

e-mail: Lin.Lerpold@hhs.se

Ö. Sjöberg

Center for Sustainability Research,

Stockholm School of Economics, Stockholm, Sweden

e-mail: Orjan.Sjoberg@hhs.se

W.-S. Tang

Department of Geography and Advanced Institute for Contemporary China Studies, Hong Kong Baptist University, Kowloon Tong, Hong Kong e-mail: wstang@associate.hkbu.edu.hk 
sustainable, than are smaller ones (Lerpold \& Sjöberg, 2021a), there is little room for complacency in a rapidly urbanising world. Theoreticians of urban scaling too admit, social ills may also scale in the same manner as do incomes, innovation and similar aggregates. Moreover, it is not a given that negative effects can be compensated for by reduced energy consumption, lower costs of infrastructure provision or by the greater ease with which public transport and opportunities for recycling and the sharing economy can be supplied.

For one thing, data may play a trick on analysis. This is so as statistics on resource use and the like typically fail to capture energy inputs, the generation of greenhouse gas emissions and similar effects that seemingly fall outside the boundaries of the city (e.g., Larsen \& Hertwich, 2009). Such "outsourced" consequences resulting from the production of intermediaries and consumption goods imported to the city are potentially substantial and may therefore change the indicators of sustainability impacts in non-trivial ways. Somewhat ironically, therefore, studies focusing on inter-urban differentiation can be said to be victims of a form of "ontological cityism" (Lerpold \& Sjöberg, 2021a), in the sense of boundaries being drawn too tightly around the production and consumption that takes place in each city part of the urban system.

For another, the trade-offs themselves are rarely addressed with any measure of positive or normative detail. Indeed, it is not unreasonable to suggest that trade-offs as exist might look very different if assessed across urban space as opposed to across the urban hierarchy. Moreover, not just the urban scaling literature but also that which celebrates the tangible agglomeration benefits to come with increased city size (e.g., Glaeser, 2011) fail to address the consequences of lifestyle preferences and rebound effects.

It is not only an issue of city size but also one of population density and urban form. Intra-city variation in density, and related to that surface and land use, are important dimensions to consider, as is the provision of infrastructure and green spaces. The dispersed city with its suburban sprawl is not likely to generate the same impact as does the compact counterpart (e.g., Bereitschaft \& Debbage, 2013; Jones \& Kammen, 2014). The same can be said of urban environments dominated by one rather than several centres or nodal points (e.g., monocentric vs. polycentric) within the urban fabric or where growth is radial (i.e., along radiating roads or other transportation corridors) as opposed to concentric. At its 
most simple, such differences in urban structure matter not least in terms of the consumption of-or the sheer dependence on-public or private means of transport.

The importance of transport for sustainability outcomes among all the dimensions of the 3 Es (Campbell, 1996) notwithstanding, urban sustainability must not be reduced to an issue of the needs of mobility and availability of transportation options alone. Land use, building construction and energy use for purposes other than transport matter, as do the activities urban dwellers engage in and the incomes they derive from their everyday pursuits. To the extent that incomes vary systematically both across size classes of towns and cities and within urban places, we may also expect that the level and structure of consumption are similarly affected. Yet, it is not a given what the net effect might be. On the one hand, the lower cost of providing critical infrastructure and services is a major benefit of large population size and high density. This is particularly so if also combined with other positive externalities, ranging from the more efficient use of land to a greater scope for the solutions of the sharing economy to traditional agglomeration effects that allow urban areas not only to economise on resources but also enhance creativity or the opportunity for introducing new products. On the other, there is little to suggest that these gains are primarily used to the benefit of the environment or for the most part result in socially equitable outcomes.

It is issues such as these that this chapter addresses. For this reason, we focus on environmental and social sustainability within the boundaries of the city. As we do so, we are mindful of the consequences of failing to consider the impact of the city beyond its boundaries, yet an analysis of intra-urban process of differentiation helps us arrive at insights that otherwise would not be available to us. More than anywhere else, this is relevant to social sustainability. For while social conditions cannot be divorced from inter-urban differentiation the effects play out at the local level. What is more, the social and the economic often set the stage for the environmental pillar of sustainability. This is not least true of how, and at the hands of whom, environmental impacts are generated. 


\section{Compact Living}

As noted above, a prominent line of research argues that there are economies of scale in resource use that put cities apart and the larger the city the greater the savings. Density and the proximity that it implies are at the heart of these benefits. Combined, these two qualities serve to trim costs and thereby help reduce the barriers to the introduction of more environmentally friendly solutions. Indeed, at first sight and at any given size level, compactness has an edge over the less densely laid out built environment, as a host of case studies attest (Camagni, Gibelli, \& Rigamonti, 2002 on Milan; Carruthers \& Ulfarsson, 2003 on the US; Næss 2006, 2012 on Copenhagen and the Nordics, respectively; Cao \& Yang, 2017 on Guangzhou and Yang, Wang, \& Ouyang, 2019 on China more generally, to mention but a few). Less pressure on what is often prime agricultural land, more efficient provision of infrastructure, a greater scope for introducing or maintaining cost-effective public transport, reduced energy consumption, better circumstances for the organising of recycling and the sharing economy, not to mention better accessibility to various amenities, are the most obvious benefits that urban dwellers can derive from living close together.

Despite these benefits, the compact city has its own sustainability drawbacks. Breheny (1992) set sight on a number of "contradictions", including those of energy efficiency, green spaces and quality of life, where the compact city might not perform as well as typically thought (see also, e.g., Gordon \& Richardson, 1997 on the US; Lin \& Yan, 2006 on Taiwan, for a selection of empirical results). "The compact city fallacy", as Neuman (2005) has it, may well lead to "town cramming" (Breheny, 1992; Hall, 2001) and urban areas characterised by high density are therefore not truly sustainable. Neuman's main point, however, is one that would resonate with Dikeç's (2001) idea of the spatial dialectics of injustice: city form is less important than process. For the student of sustainability and urban consumption as a minimum this translates into a recognition that we should expect a variety of outcomes. This is also reflected in recent research on threshold and other non-linear effects of the built environment (Ding, Cao, \& Næss, 2018; Wu, Tao, Cao, Fan, \& Ramaswami, 2019).

The quality of enhancing sustainability, or otherwise, is thus largely an empirical issue. Although this is in itself unproblematic, it also implies that at least with respect to the impact of urban form, most studies are 
case studies and that each one of them remains, in what is in fact a highly fragmented landscape of empirical findings, a case onto itself. The scope for clear-cut results that easily fit into a bigger picture are as elusive as the optimal strategy for urban sustainability itself. It bears keeping in mind though, as Næss, Saglie and Richardson (2020: 147-148) remind us, that both plans setting out to achieve densification and empirical studies that provide support for the sustainability benefits of the compact city do so on the assumption that growth is to continue. In short, they note, there is thought to be no "inherent tension between environmental sustainability and economic growth" and that, to the extent that such a tension is recognised, it "can be overcome through technological improvements and institutional reforms within the confines of the existing political-economic structure" (Næss et al., 2020: 160).

Problems do not stop there. As seen from the 3 Es' point of view, the superior economic performance of urban areas (if that is indeed what it amounts to, see Frick \& Rodríguez-Pose, 2018), does not necessarily result only in beneficial outcomes. In addition to common negative externalities such as congestion, pollution and stress, other problems are likely to make themselves felt. It is not without reason that the extensive literature on sustainability transitions perceives urban areas and "the obduracy of the existing physical built environment" as a "key barrier" rather than a source of opportunity (Nielsen \& Farrelly, 2019).

Importantly, as the costs per unit of output go down, it might result in increased absolute demand of resources; it all depends on elasticities of demand. Any such gains may also be used to improve some other dimension of performance rather than translate into lower levels of resource use as such, underlining the importance of keeping relative and absolute improvements apart. To the extent that it is the absolute level of extraction or other forms of strain on natural resources that matters, this is of some consequence. Higher productivity also spells higher incomes, which in turn can be spent wisely or unwisely as assessed from an environmental point of view. Even potential gains from sharing economies may incur "respending rebound effects" (Laurenti, Singh, Sinha, Potting, \& Frostell, 2016) which may result in an even higher negative environmental impact. Similarly, depending on how the gains from cost savings and productivity improvements are distributed, not just environmental but also social sustainability effects are likely to differ, perhaps substantially so. Circumstances, be it of the contingency or context variety, may well decide. 


\section{Casting the Net Wider}

As indicated above, economic and social sustainability are also part of the full picture of impacts. Although social sustainability is conceptually something of the stepchild of the urban sustainability literature (Shirazi \& Keivani, 2017; Vallence, Perkins, \& Dixon, 2011), it is not out of place to suggest that many processes and outcomes, including the causes with respect to the nature and magnitude of rebound effects, if any, are to be found outside the environmental realm proper. Like lifestyle preferences, it is more likely to issue from economic and social conditions as applicable. Thus, although incomes and preferences are often seen to interact with urban form to condition the specifics of travel demand in the dense and the dispersed city alike, it is not merely a dimension to be controlled for in studies of travel behaviour. Economic and social circumstances need to be tackled head on. For one thing, induced behaviour directly affects the efficacy of policy, which therefore needs to consider factors beyond the environmental (e.g., Font Vivanco, Kamp, \& van der Voet, 2016). For another, economic and social sustainability, important in their own right, may come in direct conflict with environmental sustainability, the resulting trade-offs requiring both a deep understanding of all 3 Es and clear priorities. Again, while there are important issues of principle at stake, actual outcomes are often difficult to predict. Context matters.

This being the case, what does the empirical literature suggest? As a first cut, there is surprisingly little empirical evidence to start with. Despite the recent suggestion that "[a] strength of the literature [on urban sustainability] is a focus on the social sustainability aspects of urban development" (Armstrong \& Kamieniecki, 2019: S55), empirical studies are at once few and for the most part narrow in scope (geographically or by sustainability dimension). This is of course not to suggest that there are no studies on the topic. Interestingly some studies suggest that there might be trade-offs also between different types of social sustainability, for instance as relates to equity and community (Bramley \& Power, 2009).

This might in turn explain why there is no consensus or universally valid answer. City size and density tend to correlate with inequalitythe larger the city, the more unequal-yet the sources of this pattern are contested (Lerpold \& Sjöberg, 202la). Productivity and wages, rents from land and capital gains from real estate in growing urban areas are all 
conceivable, as is firm size, the level of affluence and the impact of globalisation. That it often also translates into segregation is uncontroversial but tells us little about the causes of the patterns observed.

As for the distribution of the productivity gains, research has suggested that most, if not all, of the rents that accrue go to landowners rather than employees who see their productivity rise as a result of the urban location. These results, however, are contingent upon a number of simplifying assumptions on the distribution of skills (i.e., the labour force being homogenous in this respect). Introducing variation in such skills, or for that matter in housing demand and preferences, tends to shift the distribution at least to some degree away from landowners in favour of employees and residents (Collier \& Venables, 2018). As with much work on the issue of distribution of rents, starting at least with Beckmann (1969), the latter are model results though, not as yet empirically confirmed findings.

The implications for our efforts to summarise and assess research on urban consumption are as clear as they are painful. As often as not, we may expect a large number of empirical studies that are hostage both to local context and to an eclectic set of methodologies and methods. Although such pluralism is not to be frowned upon, it is as likely a result of the scope of an analysis hinging on data availability as being an expression of the cumulative advances that is the hallmark of scientific advancement.

With this in mind, in the following we will detail the current state of the art. Following on the heels of a discussion on the possibility of rebound effects, including in densely built areas that seem to have an edge with respect to the sharing economy, we move on to consider mobility and the built environment. The latter includes some attention to housing, but the probably most widely discussed social sustainability issue related to housing, that of segregation and gentrification, is given a sub-section of its own.

\section{Sharing Economy Business Models, Consumption ANd Lifestyle Changes: Rebound Effects?}

Business models based on a sharing economy idea has gained traction among new business ventures as well as policymakers as a system changing sustainability idea. For instance, products and services such as Voi's electricity driven scooters (Reuters, 2019), Filippa K's clothes lease (Hendriksz, 2015), Airbnb or Uber (Forbes, 2019) all make claims of 
having sustainability as driver for their business model. Policymakers are also considering sharing economy models as can be witnessed for instance in the Swedish Government's strategy for sustainable consumption (MoF, 2016). Simultaneously, consumption and lifestyle changes with sustainability claims closely connected to individual identity and image seem to be gaining ground. Examples such as flygskam (flight shame; BBC, 2019), environmentally friendly multiple use shopping bags, electric cars and recycling habits are lifestyle trends first seen in urban areas and oftentimes connected to city dwellers' socially constructed identity. Building on Amartya Sen's (1984) position that our relationship to material artefacts is socially constructed and connected to our relationships with others, what we consume of products and services, impacts both how we see ourselves as well as how we project our image, thus very much connected to our chosen lifestyles.

Less is known about what has been called the rebound effects from sharing economy sustainability gains or impacts from lifestyle preferences in the sustainability domain. The "sustainability paradox of the sharing economy" (Verboven \& Vanherck, 2016) refers to the unintended negative side effects or externalities at a behavioural and systemic level, associated with moving from the old to the new, presumably more sustainable model. A rebound effect is defined as an increase in consumption that may occur as an unintended consequence of the introduction of policy, market and/or technology intervention aimed at environmental efficiency improvements (Maxwell, Owen, McAndrew, Muehmel, \& Neubauer, 2011). Consumer gains in purchasing power resulting from sharing economy models may lead to increased consumption in the same now less costly model (direct rebound effects) or an increase in other products or services (indirect rebound effects) that may be even less sustainable.

For instance, supported by a number of government tax subsidies as well as other incentives such as car-pooling lanes, free charging, toll fees and parking in cities, the Norwegian market for electric cars is the largest per capita in the world (Nikel, 2019) but may at the same time have large direct rebound effects. Driving an electric vehicle where the quickest uptake has been within urban settings is very much associated with a sustainable lifestyle identity and image change. What is less discussed is that the typical Norwegian electrical vehicle buyer owns two cars: one run on traditional petrol or diesel and used for vacations and longer journeys, the other an electric car used for everyday commuting and 
leisure activities that might instead have been covered by public transportation (Haugneland \& Hauge, 2014). Indeed, such vehicles may add to the crowding of the lanes set aside for public transport (which electric cars have so far been allowed to use), thereby further reducing the attractiveness of a still more environmentally friendly option (Aasness \& Odeck, 2015). Another example of a direct effect can be found in the uptake of second-hand or leased apparel in urban environments. From a circular economy perspective, second-hand apparel and leased clothes can have a larger negative environmental impact depending on the mode of distribution and purchase behaviour of consumers in addition to adding second-hand and leasing to original apparel consumption purchases (Roos, 2017). Thus, consumers add the goods and services they can afford within the sharing economy resulting in higher consumption instead of a replacement of normal consumption.

Indirect rebound effects are understood when for instance, urban dwellers can reap the cost savings from more efficient emissions from residential energy usage. In a study by Underwood and Fremstad (2018) focusing on expenditure data for households sharing carbon intensive goods such as residential energy usage and private vehicle transportation within and between households in the United States, showed that the positive impacts from reduced carbon were offset by increases in consumption for air travel and restaurant meals. Numerous other such examples connected to sharing economy business models and changes in consumption and lifestyle initiated among sustainability conscious urban dwellers must be approached with caution. If flight shame makes an impact, are the savings in purchasing power and $\mathrm{CO}_{2}$ emissions from reduced flying being offset by other types of consumption such as increased purchases of second cars or apparel? As sharing economies continue to be hailed uncritically as a magic bullet to sustainable market systems, further empirical research, also taking a circular economy perspective beyond methodological nationalism and ontological cityism, is needed to understand whether or not the sum of all vices may indeed be constant.

\section{Mobility}

Given the underlying property of modern economies, spatial exchange is inevitable. There is also typically a separation of residence, work and access points where goods and services could be obtained (or increasingly are 
shipped for home delivery). As a consequence, mobility and accessibility are core considerations for the form of lives we lead, and the infrastructure needed for it is naturally an integral part. This is true across scales, from the local to the global. From a sustainability point of view, it has a number of straightforward traits and quite a few that are far more complicated. The environmental burden imposed by transportation, be it of persons or goods, belong to the former while the trade-offs between the 3 Es will make us inch in the direction of ever greater complexity.

This is reflected in the literature on sustainable mobility (Holden, Gilpin, \& Banister, 2019) and in the literature on urban sustainability more generally. The environmental impacts of urban consumption, often in the form of $\mathrm{CO}_{2}$ emissions, take pride of place. Economic sustainability is often discussed in terms of the benefits of dense environments but also conflicts between negative externalities (congestion, pollution, safety) on the one hand and the gains from specialisation on the other has increasingly come into focus (Ahlfeldt \& Pietrostefani, 2019; Ahlfeldt, Pietrostefani, Schumann, \& Matsumoto, 2018; del Mar Martínez-Bravo, Martínez-del-Río, \& Antolín-López, 2019). Another common theme is urban regeneration and its pecuniary costs and social impacts, often approached from a normative or planning angle (e.g., Wheeler, 2013) or as part of the discussions on segregation and gentrification. Thus, despite the extensive literature on accessibility, be it to job opportunities, to public and private services, to amenities in general (e.g., Curtis and Scheurer, 2010; Kwan, Murray, O'Kelly, \& Tiefelsdorf, 2003), other than on public transport provision as such there are surprisingly few that explicitly couch this in terms of mobility and economic or social sustainability. The recent and very useful survey of Ahlfeldt et al. (2018: 24) include only 35 such studies (out of 321 surveyed), the general thrust of which suggests that density has a positive influence on accessibility.

Perhaps this matters less as the literature on mobility and transportation mode choice is quite uniform as to the results generated. As Ewing and Cervero (2010: 265) conclude in a widely cited meta-analysis,

[c] onsistent with prior work, we find that vehicle miles travelled (VMT) is most strongly related to measures of accessibility to destinations and secondarily to street network design variables. Walking is most strongly related to measures of land use diversity, intersection density, and the number of destinations within walking distance. Bus and train use are equally related 
to proximity to transit and street network design variables, with land use diversity a secondary factor.

Things might not always be that straightforward. For instance, they also find that the density of population or jobs are not particularly strongly correlated to travel behaviour, at least not once various socio-economic factors have been taken into account (Ewing \& Cervero, 2010: 275). Additionally, social identity may be a stronger motivation for an individual's choice of transportation than accessibility or proximity to transit (Heinen, 2016).

As a consequence, the role of size, density and urban form in generating $\mathrm{CO}_{2}$ emissions from transportation is not universally identical. While it is often the case that urban areas see increases in energy use for mobility ends as densities go down, it is also at times the case that monocentric cities perform less well in this respect than do polycentric ones (e.g., Makido, Dhakal, \& Yamagata, 2012). Rather than primarily being an issue of population density, however, it may also boil down to an issue of topography (think attractiveness of commuting by bicycle) as well as shape compactness-circular form being more conducive to transport minimisation than radial, elongated etc. or other shapes-as Angel, Franco and Liu (2020) show. In addition to that, if studies are not conducted using commuting sheds, we are at a loss to appreciate the true impact of urban carbon emissions from fuel consumption. Analyses based on residents in the analysed area (e.g., a municipality) rather than travel to jobs located there is likely to underestimate the true state of affairs (Aguilér \& Voisin, 2014), in turn exaggerating the positive benefits of urban concentration and density. Yet again it appears that the choice of basic spatial unit of analysis matters, ontological cityism serving to restrict our field of vision (Lerpold \& Sjöberg, 202la).

This being a very active field in transportation research (Nikulina, Simon, Ny, \& Baumann, 2019), it is beyond the scope of this review of urban consumption to detail its findings. It does generate a few further reflections, though. One is that accessibility is not merely a question of how to reduce the need for transportation services. As Waters (2016: 46) notes, the notion of accessibility carries with it a wider normative orientation: it "directly addresses nuances of urban development such as power and justice". Hence social sustainability cannot be left out, as not least the extensive literatures on urban food deserts and food swamps (Rose et al., 2009; Shaw, 2006) and urban transport justice 
(Gössling, 2016; Martens, 2012) attest. The latter includes socially variegated exposure to risks (traffic accidents and noise, pollutants), the use of space, accessibility and time used for transportation.

Another is that, as we look forward, we may also see considerable changes as the relative weight of e-tailing relative bricks-and-mortar shifts, including not only on environmental sustainability outcomes but also on urban areas themselves. For now, however, as most literature appear to indicate that the online channel with home delivery might be less of a burden on the environment than is traditional shopping, it remains an empirical issue and, as Horner et al. (2016) notes, user behaviour is at the core of it all. (Besides, one might argue, in neither case is it particularly sustainable.) Likewise, as noted above, the effects of the sharing economy is an emerging but largely empirical issue: will the sharing of cars lead to fewer cars in motion on our streets or will it serve to reduce the relative attractiveness of public transport (Möller, Daschkovska, \& Bogaschewsky, 2019)?

A further point is the dynamics that come with increased levels of urbanisations and, with it, changes that are likely to have sustainability implications that we do not fully grasp today. Consider Batty's (2013: 39) observation that "[a]s cities get larger, there are less of them", implying not only that mobility needs within but also between urban centres will change as regards the flow of goods and persons. Again, whether this will provide a more beneficial net outcome in terms of energy use or not is an empirical issue not yet investigated as far as we are aware (but on trade, see e.g. Peters, Minx, \& Edenhofer, 2011). On a similar note, while increased urban density might well reduce greenhouse gas (GHG) emissions caused by driving, indications are that more densely built urban regions also contribute out of proportion to long distance travel, including by air (Czepkiewicz, Heinonen, \& Otellin, 2018; Czepkiewicz et al., 2008; Holden \& Norland, 2005; Underwood \& Fremstad, 2018).

\section{The Built Environment and Housing}

As outlined above, urban size as well as form or morphology influence mobility needs and choices and as a consequence have an impact on energy consumption and the resulting emissions. The effects of the built environment are more far-reaching than this, however. The use of urban land has a number of effects that range from micro-climate to the opportunities to reshape the urban layout and texture with a view to 
introducing more sustainable designs and practices. The appurtenances of land - that which is built upon or else added to the individual lotnot only reinforces the relative low plasticity of the built-up environment, it also has consequences in the form of demand for steel, concrete and other building materials. The production of at least the former two are among the main sources globally for GHG. Density but also layout, social diversity, walkability and many other traits of the urban contribute in various ways to economic viability and possibly sustainability, its social sustainability qualities being similarly influenced.

Again, under conditions of the continuing urbanisation of the world population, effects in absolute terms are greater in urban areas, yet need not be more demanding or wasteful in per capita terms. As the IPCC 2014 Report notes, at least with respect to GHG emissions the large differences across urban areas in terms of population, area, size and density make generalisation impractical (Revi et al., 2015), yet as part of its principles of sustainable neighbourhood planning, UN-Habitat (2014) recommends a density of 150 inhabitants per hectare and also that road density should be high (to cover at least 30 per cent of the surface) while neighbourhoods should be functionally mixed. The latter translates into mixed land use including residential, workplaces and services space (with economic use allocated at least 40 per cent of total floor space in any neighbourhood; conversely, mono-functional blocks should at most cover 10 per cent of a neighbourhood). All of these issue from sustainable transportation needs, including the promotion of walkability and vibrant street life, but pay little attention to land use impacts of the built environment beyond energy use for mobility ends (i.e., by reducing transportation needs and costs for accessing workplaces and services). The final principle is of a distinctly different nature, as it targets the social mix, both in terms of incomes and housing tenure forms: $20-50$ per cent of the total housing area should be of the affordable housing type and any tenure form should not surpass the 50 per cent threshold of the total housing space available.

If only it was that simple! Follow the principles and things will work out to the benefit of society, including in the form of more just cities that are less troubling from a climate change perspective. However, compactness turns out to have very different impacts across types of accessibility to amenities of various sorts. What remains one of the most comprehensive empirical studies to date, Burton (2000), on 25 English cities and towns, found that out of the ten social impacts claimed in prior literature to affect 
low-income groups, only three (reduced social segregation; lack of affordable housing; better public transport) were in line with expectations. Out of these three, two imply superior performance of the compact city. As for the others, four were ambiguously or only partly supported (better access to facilities; poorer access to green space; reduced domestic living space; poorer health). Better accessibility to jobs returned a question mark and expectations for reduced crime were turned on their head.

By and large, these results are confirmed in later studies, usefully summarised in Ahlfeldt et al. (2018), although it should be noted that outcomes in low- and middle-income countries do at times differ from those of urban areas in high income countries. As such, it contributes towards a better understanding of sustainable cities, yet it leaves out issues such as lifestyle and other consumption preferences. As Ewing and Hamidi (2015: 416) put it, "the American Dream consists of a large lot home in the suburbs". Furthermore, it says little about the impact of construction activity as such.

Although assessed as part of the dominant green building certification scheme, that of Leadership in Energy and Environmental Design (LEED), construction, building materials and construction waste are all important generators of environmental impacts that often take second seat to considerations such as the use of energy, water and other resources as the building is used. Yet the former may have a larger impact than do the latter (e.g., Francart, Malmqvist, \& Hagbert, 2018). If so, urbanisation and urban growth itself becomes a problem that is not, as Nrss et al. (2020) noted, readily appreciated in the type of studies that have dominated the discussion on whether or not urban areas are more or less sustainable than are non-urban areas. For, with urban growth comes a need for construction work that impacts not least the ecological $\mathrm{E}$ of the 3 Es. Land use change itself has an impact, including if it leads to change in the direction of hard (and often dark) surfaces that serve to reduce the capacity for diffuse reflection. The same applies to the production, transport and waste management of building materials. Construction machines are a major source of emissions and all of this may additionally contribute to the generation of so-called black carbon (relatively short-term particles resulting from the use of fossil fuels). In short, assuming a life-cycle perspective is likely to change the picture.

If it is true that "a sustainable mode of urban living is the only way that we will be able to sustain social life as we know it" (James, 2015: 6), we also need to look at choices made of urban dwellers that cannot be 
brushed away as merely a consequence of being based in a densely built environment. As we are concerned specifically with urban consumption, this implies that we need to think in terms of lifestyle and consumption choices, including activity patterns, where consumers have considerable leeway in deciding the what, how and how much they consume, yet might systematically do so in a fashion different from people living outside urban areas. For one thing, it is a widely held view that urbanites tend to consume more than their peers elsewhere (Bradley, Hult, \& Cars, 2013), including travelling more once leisure travel is added to regular everyday mobility (Holden, 2004). As also casual observation would suggest, as regards one form of consumption, that of housing space, this is patently not the case: on average, that particular aspect of consumption is inversely related to city size and intra-urban density. In terms of pecuniary outlays, however, the reverse is probably true, suggesting that the unit of analysis is of some consequence.

Although most work on housing renovation is connected either to the issue of energy efficiency or to gentrification (on the latter of which more in the following), there is also some evidence to the effect that residents are more likely to put money into repairs and renovation if the value of their home is high (Gyourko \& Saiz, 2004; Plaut \& Plaut, 2010). If so, it is not only an issue of what is economically meaningful but to the extent that renovation is less of a burden on the environment than is new construction this would be perhaps a somewhat surprising benefit of one of the negative externalities of increasing city size. Yet, as this can also be linked to large-scale renovation projects, often for structural maintenance and energy efficiency ends, it becomes obvious that there is a social side to it all that need to be taken into account (Astmarsson, Jensen, \& Maslesa, 2013).

\section{Segregation and Gentrification}

While "renoviction", that is, renovation as a means of chasing tenants away, may have emerged as a hot (and contested) issue of late, two other phenomena dominate discussions on the social sustainability of cities. This is residential segregation, either by social standing (income, class, etc.) or ethnicity, and gentrification. Both have long attracted attention, including as an outcome and a process. It is beyond the scope of this chapter to detail all the debates, including those on theory and causes, that have 
evolved across time and space but the relevance for social sustainability is evident. It has also long been on the urban planner's agenda.

Although the consequences of segregation may not by necessity all be disadvantageous - for instance ethnic enclaves are occasionally seen as providing opportunities (e.g., Martén, Hainmueller, \& Hangartner, 2019; Xie \& Gough, 2011 for two opposing views) - it is widely recognised that segregation is a considerable strain on a host of social and economic phenomena. It tends to spill over to discussion on workplace segregation and access to urban space. It has also long been recognised that real estate markets not only reflect the existence of residential segregation but that they often also have a role in creating, maintaining, preventing or mitigating it. In turn, segregation may well shape labour market outcomes. The role of policy in all of this is also contested, if in very different ways and for very different reasons (partisan politics and ideology not being alien considerations here). Closely connected to processes of segregation in urban space is the emergence of gated communities, which depending on one's point of view can be seen as either an intentional social exclusion through the privatisation of public space or as a means to solving problems of local public goods provision and the protection of common pool resources.

Since the term of gentrification was coined by Ruth Glass to represent an urban phenomenon taking place in London half a century ago, it has been widely applied around the world. New residents, the social status of whom differs from existing residents are thought to crowd out the original residents. The newcomers being richer and more knowledgeable about so-called rent gaps (the difference between current and potential rents to be reaped from the existing stock of real estate), displace the original inhabitants. The social status and image of the area is 'upgraded' as the new residents renovate buildings and have an impact on the composition of local area commercial and social services. Yet, as is also true of renoviction, the extent to which gentrification in fact results in displacement remains contested in its own right. There is wide agreement, however, that it may well take place and it has been documented to happen for instance in the wake of tourism development (in this handbook, Lerpold \& Sjöberg, 2021b) and in large-scale urban development projects around the world.

As especially parts of Europe and North America have become more environmentally conscious, the concept of green gentrification has also been recently invented to handle issues of sustainability related to such 
an urban phenomenon (Dooling, 2009; Gould \& Lewis, 2017). While the creation and restoration of urban amenities has been highlighted in green gentrification arguments, many imminent issues have remained unresolved, including ecological benefits of greening and increased environmental impacts of new resident lifestyle; the role of finance capital and financialisation of urban greening; access to green amenities for long-term residents; procedural justice in the planning and design of green amenities; and greening and health related to displacement and dispossession.

Two further points are noteworthy. First, there is a call for international comparative analysis to address how green gentrification has been materialising in the Global South (Anguelovski, Connolly, Garcia-Lamarca, Cole, \& Pearsall, 2019). Besides, Krueger (2017) argues emphatically for critical sustainability studies to interpret urban sustainability within the perspective of conceptualising urbanisation as a process, a sentiment that is close to that of Neuman (2005) already mentioned. These two points together urge us to elaborate on, as a supplement to the aforementioned literature, gentrification and sustainable development in Asia, given their more specific urbanisation processes.

It has forcefully been argued that gentrification may not be an appropriate concept to denote the urban processes at work everywhere (Maloutas, 2011). In Asia, not just the city states of Hong Kong and Singapore but also the major metropolises in China, India and Indonesia are cases in point (Benjamin, 2008; Benjamin \& Bhuvaneswari, 2011; Ghertner, 2015; Haila, 2016; Kusno, 2013; Lee \& Tang, 2017; Shatkin, 2017; Tang, 2014, 2017; Wong, 2019). Central to the argument is that in these cities, there are complicated land relationships at work. Besides specific colonialisation histories, there are, for example, the freehold vs. quasi-Chinese customary land practices in Hong Kong, the state ownership vs. collective ownership in Chongqing and other mainland Chinese cities, and the formally registered BPN vs. the informally registered kelurahan in Jakarta. It is not the prevalence of dualistic systems (legal vs illegal; inside vs. outside the law; formal vs. informal; owner vs. tenant, etc.) that counts. It is the intricate intermeshing of these spatial practices over time, or as Tang (2019) has elaborated, the mutual embeddedness of complementary opposites that has produced urban processes and forms beyond the comprehension of concepts like gentrification, needless to say even the truncated concept of variegated gentrification. Instead, 
with reference to the Hong Kong case in particular, we may speak of hegemonic-cum-alienated redevelopment (Tang, 2017).

Due to the functioning of the hegemony between capital and state, the claimed advantages of green gentrification in the West and the North have seldom materialised in Asia. For example, the self-proclaimed environmental balcony in each flat associated with redevelopment projects in Hong Kong, which are usually of no practical, material use value, has seldom benefitted the general public and seldom represent win-win benefits for all. In contrast, the benefits have been captured by the land market, which is in turn deployed by the state for the strategic distribution of economic benefits to the land capital, be it in Hong Kong (Tang, Lee, Hui, \& Yip, 2019) or Jakarta (Kusno, 2013). In other cases, they have been rationalised as part of the ideological project of ecological and social transformation, and national unity too. Procedural justice seldom prevails in Asian cities, as the underprivileged are usually excluded from the planning and administration of redevelopment and green projects. This has happened to, for example, many peasants living in old villages within cities in China. The negative side effects of (re)development have been borne by existing residents who are usually dispossessed and displaced to housing in the periphery, with social segregation deepening as a result. Small shops, bazaars and household businesses have also been forced away in development projects where, in a parallel to slum clearances around the world, displacement in effect precedes the intended change in social composition. Recently in Hong Kong, less privileged households, who however are long-time residents in the city have been expelled by investment-migrant flat-purchasers from mainland China. There are many such examples of negative spill-overs of (re)development across territorial boundary. One is that of Singapore, where externalities have been borne by residents in Malaysia and Indonesia, another is Hong Kong where the negative externalities are passed on to the Pearl River Delta in its vicinity.

\section{Further Issues in Social Sustainability}

Many social sustainability issues are more salient in densely populated areas such as in big cities than in either towns or rural areas. Yet the relationship between some social issues (say, displacement) and the size and density of the city is less clear than is the case in others. For instance, crime rates in general are higher though of a different nature in cities relative to towns and rural areas (Ellis, Farrington, \& Hoskin, 2019: 
149-156; Glaeser \& Sacerdote, 1999) and a larger proportion of homeless are found in urban areas (Susser, 1996; Wolch, Dear, \& Akita, 1988). Yet, this literature also reveals the complexities in understanding whether social sustainability is positive or negative in cities. For instance, though proximity and the potential benefits of natural surveillance in the built environment, such as windows overlooking streets might lead to a perception of security, poorer conditions and the "broken window syndrome" may instead lead to increased anti-social or even criminal behaviour (Wilson, 1985: 78). It may even be that detailed urban design is more interesting than density per se. In yet other cases, density, social factors and urban design (such as poor visibility) combined are associated with high crime rates. Thus, outdoor rape tends to take place close to the neighbourhood of the offender or in inner-city locations, in both cases combined with poor visibility but with good escape routes (Ceccato, 2014). Of course, the relationship and causality of social issues and urbanity is less clear, in that, economic opportunities of more populated urban areas may attract more crime-prone and homeless individuals as opposed to the notion that urbanity in itself leads to higher crime rates or homelessness.

Social sustainability and urban form can be divided into two main dimensions of social equity and sustainability of community (Bramley, Dempsey, Power, Brown, \& Watkins, 2009). Whereas social equity concerns the potential and economic viability for better access to services and opportunities because of higher density, sustainability of community concerns those dimensions oftentimes conceptually distinct but relationally interlinked, and negatively associated with urban dwelling. These include, for instance, sense of, and participation in community; safety and security; stability and residential turnover. Though higher densities may more often provide the opportunity of meeting each other on the street than in lower density areas (Duany, Plater-Zyberk, \& Speck, 2001), alternative arguments maintain that higher densities in cities may lead to weaker social ties (Freeman, 2001) and that the oftentimes higher multicultural diversity found in urban areas may break down trust and the social capital needed for social interaction and integration in communities (Putnam, 1993). That there is no unambiguous or direct link, however, is made clear by the diverse strands of research on "lived diversity" (e.g. Wessel, 2009) and effects are in part hostage to the scale at which problems are assessed. Indeed, both high levels of segregation and inner-city decay is often associated with suburban sprawl (Bramley \& Power, 2009). 


\section{Beyond Social Ills: Consumption Patterns}

Social sustainability is not only an issue of social ills such as displacement and homelessness, delinquency or the erosion of generalised trust. More ordinary phenomena might prove important for the overall effects. Thus, also as the division of labour upon which urban areas rest need not preclude own production for household needs-neither urban agriculture and allotment gardens nor guerrilla gardening are unknown entities as is also true across a wider range of activities for own use-market transactions are a main feature of urban life. And markets might serve both to support and undermine sustainability.

Almost invariably, market exchange implies some form of transportation, perhaps over digital networks, more often over considerable distances. As a consequence, also a fully decarbonised local economy might generate quite some impact as the need for imports are not ever likely to go away (e.g., Clarke, Heinonen, \& Ottelin, 2017). Looked at from the angle of consumer choice, three potential explanations emerge from the discussion up to this point. Thus, the need for car ownership is linked to issues such as city size, shape and density but also access to public transport, sprawl being a prime inducement for households to acquire cars. It is also easy to imagine that other factors such as household size, life-cycle and activity patterns, social identity and many other besides, are all likely to have some impact on car ownership. Pure utility is thus unlikely to play the only role and car ownership and use will depend on incomes. The spatial sorting that occurs implies that average incomes are likely to increase as we move up the urban hierarchy. While higher income does not necessarily imply higher disposable income, in particular not if housing costs are taken into consideration (Korpi, 2008), chances are that a good number of residents of major urban centres can afford it. Which of course is not to suggest that everyone does.

Precisely for this reason the third potential explanation, influence from one's peer-keeping up with the Joneses, for instance-cannot be discounted. While such factors operate across a wide range of goods, it is easy to imagine that car ownership in particular might be subject to such forces. Add to this the effects of marketing efforts, including the ability to create a sense of perceived product obsolescence, and lifestyle factors quickly come to the fore.

Potentially, though, effects could go in either direction. The sharing economy, Cohen (2016: Ch. 3) notes, needs to be thought of as a source 
of multiple and contradictory outcomes across several markets. As our discussion of rebound effects suggests, the useful sharing of tangible resources might in parallel induce or allow for increased consumption of other goods or, say, imply socially unsustainable labour market impacts. We have pointed to the importance of income effects as source of such ambivalent directionality, but also peer effects may matter (Manski, 1993). As the debate on flygskam shows, as consumers we are indeed exposed to social pressure. Assessing it from a sustainability point of view, also such pressure can be a mixed blessing or detriment. Yet instances of positive peer effects do exist and a set of studies detailing the adoption of solar photovoltaic systems by households may serve as an example (Curtius, Hille, Berger, Hahnel, \& Wüstenhagen, 2018; Graziano \& Gillingham, 2015; Palm, 2017).

\section{Conclusion}

If there is one trait that might serve to characterise the issue of urban sustainability, ambiguity would be a strong candidate. Not only are scholars divided by the stance on the sustainability of urban living as we know it, theories, models and empirical results as they exist across the 3 Es-ecology, economy and equality-do not point in one direction. This review has only highlighted a few of the complexities that are a key attribute of the field, the lack or indeed unfeasibility of universally valid theorising (as in the case of gentrification, green or otherwise) or unambiguous aggregation of empirical findings prominent amongst them. Furthermore, just as many issues have to be settled on empirical grounds, and that the empirics often do not add up to a complete picture, it is equally clear that there is no lack of trade-offs across the various forms of sustainability striven for. Could it be that the trade-offs not only call for a strong sense of priority, but that the very notion of urban sustainability is an oxymoron?

The literature has a clear emphasis on environmental impacts, much of it focused on energy use and transportation, less so on building construction materials and activities. Meanwhile, the notion of economic sustainability is often treated as if it was unproblematic: a positive revenue stream is needed to allow businesses and urban governments alike to further the causes of environmental and social sustainability. Social sustainability focuses on inequitable access and socio-spatial differentiation, the twin process of segregation and gentrification being a main area 
of research. As for the latter, green gentrification is only one of the latest strands, one that points in the direction of the potential displacement both of existing inhabitants and environmental problems. As such, it puts the issue of urban sustainability in stark light: rarely is the confluence of the 3 Es so visible to the plain eye.

Importantly, however, in most of these instances-and that is also true of research on gentrification where theoretical debates have waged back and forth for several decades - there is still a need for finding explanations and identifying causes, not just empirical patterns. These empirically diverse patterns also reflect the diversity of processes observed across the globe, universal claims often being unhelpful. It also adds up to a limited or fragmented understanding of the conflicts that Campbell (1996) identified. Trade-offs there are, and obvious they might be, but much remains to be done on how to resolve them, to mitigate their effects or simply how to establish procedures on how best to discriminate among them with respect to their relative importance.

This poses a problem also for policy as it is not self-evident what works and what does not or whether universal policies or selective interventions are called for. Infrastructural systems or the sheer path dependence in technological systems pose problems that are not easily solved at the local level. At an equally practical but more micro level, consumption patterns and the behaviour of consumers may hold a key for more sustainable outcomes, not least because the effects often transcend the setting where consumption takes place. Therefore, would it be possible to promote pro-sustainable behaviour among urban residents? Many think so, and psychological theories of affordances as much as the possibilities of making use of nudging have been advanced for the benefit of the cause (e.g., Kaaronen, 2017; Mehan, 2017) or to move beyond the perceived impasse of human-environment relations in modern urbanism (Marcus, 2016).

As is the case with many of the observations detailed in this review and its companion chapter (Lerpold \& Sjöberg, 2021a), they hold out the promise of being able to achieve a relative decoupling of sources of unsustainable practices and impacts on the one hand and growth and improved material welfare on the other. Yet, the track record suggests that such positive change is often elusive: none is likely to make but a minor contribution (if any at all) to the goal of absolute decoupling. We have underlined the role and nature of rebound effects as one important obstacle but there is more to it. Precisely because "[n]on-sustainable 
production and consumption levels are primarily a result of our desire to do more, experience more, see more, and, to put it briefly, consume more" (Holden, 2004: 92) either complete decoupling will have to succeed or else the only option is to cut back on consumption. Because of the importance of major cities in setting the standard, the work to achieve decoupling would benefit from starting there.

Acknowledgements The work leading up to this contribution has in part taken place within the project "Urban sustainability, sustainably urban? The importance of interlocked markets to (un)sustainable outcomes in Stockholm and beyond". Generously funded by the Marianne and Marcus Wallenberg Foundation (project MMW 2017.0060), the support is hereby gratefully acknowledged.

\section{REFERENCES}

Aasness, M. A., \& Odeck, J. (2015). The increase of electric vehicle usage in Norway-Incentives and adverse effects. European Transport Research Review, 7(4), art. 34.

Aguilér, A., \& Voisin, M. (2014). Urban form, commuting patterns and $\mathrm{CO}_{2}$ emissions: What differences between the municipalities and its jobs? Transportation Research, Part A: Policy and Practice, 69, 243-251.

Ahlfeldt, G. M., \& Pietrostefani, E. (2019). The economic effects of density: A synthesis. Journal of Urban Economics, 111, 93-107.

Ahlfeldt, G. M., Pietrostefani, E., Schumann, A, \& Matsumoto, T. (2018). Demystifying compact urban growth: Evidence from 300 studies from across the world. (OECD Regional Development Working Papers, 2017/03). Paris: OECD.

Angel, S., Franco, S. A., Liu, Y., \& Blei, A. M. (2020). The shape and compactness of urban footprints. Progress in Planning, 130, art. 100429.

Anguelovski, I., Connolly, J. J. T., Garcia-Lamarca, M., Cole, H., \& Pearsall, H. (2019). New scholarly pathways on green gentrification: What does the urban 'green turn' mean and where is it going? Progress in Human Geography, 43(6), 1046-1086.

Armstrong, J. H., \& Kamieniecki, S. (2019). Sustainability policy research: A review and synthesis. Policy Studies Journal, 47(S1), S45-S65.

Ástmarsson, B., Jensen, P. A., \& Maslesa, E. (2013). Sustainable renovation of residential buildings and the landlord/tenant dilemma. Energy Policy, 63, 355362 .

Batty, M. (2013). The new science of cities. Cambridge, MA: MIT Press. 
BBC. (2019). What is flygskam? Greta speaks up about 'flight-shaming'. BBC, London, 19 July [online]. URL https://www.bbc.co.uk/newsround/490 32117. Accessed 4 October 2019.

Beckmann, M. J. (1969). On the distribution of urban rent and residential density. Journal of Economic Theory, 1(1), 60-67.

Benjamin, S. (2008). Occupancy urbanism: Radicalizing politics and economy beyond policy and programs. International Journal of Urban and Regional Research, 32(3), 719-727.

Benjamin, S., \& Bhuvaneswari, R. (2011). Illegible claims, legal titles, and the worlding of Bangalore. Revue Tiers Monde, 206, 37-54.

Bereitschaft, B., \& Debbage, K. (2013). Urban form, air pollution, and $\mathrm{CO}_{2}$ emissions in large U.S. metropolitan areas. Professional Geographer, 65(4), 612-635.

Bradley, K., Hult, A., \& Cars, G. (2013). From eco-modernizing to political ecologizing: Future challenges for the green capital. In J. Metzger \& A. R. Olsson (Eds.), Sustainable Stockholm: Exploring urban sustainability in Europe's greenest city (pp. 168-194). New York: Routledge.

Bramley, G., Dempsey, N., Power, S., Brown, C., \& Watkins, D. (2009). Social sustainability and urban form: Evidence from five British cities. Environment and Planning A, 41(9), 2125-2142.

Bramley, G., \& Power, S. (2009). Urban form and social sustainability: The role of density and housing type. Environment and Planning B: Planning and Design, 36(1), 30-48.

Breheny, M. (1992). The contradictions of the compact city, a review. In M. Breheny (Ed.), Sustainable development and urban form (pp. 138-159). London: Pion.

Burton, E. (2000). The compact city: Just or just compact? A preliminary analysis. Urban Studies, 37(11), 1969-2006.

Camagni, R., Gibelli, M. C., \& Rigamonti, P. (2002). Urban mobility and urban form: The social and environmental costs of different patterns of urban expansion. Ecological Economics, 40(2), 199-216.

Campbell, S. D. (1996). Green cities, growing cities, just cities? Urban planning and the contradictions of sustainable development. Journal of the American Planning Association, 62(3), 296-312.

Cao, X., \& Yang, W. (2017). Examining the effects of the built environment and residential self-selection on commuting trips and the related $\mathrm{CO}_{2}$ emissions: An empirical study in Guangzhou, China. Transportation Research Part D: Transport and Environment, 52(B), 480-494.

Carruthers, J. I., \& Ulfarsson, G. F. (2003). Urban sprawl and the cost of public services. Environment and Planning B: Planning and Design, 30(4), 503522. 
Ceccato, V. (2014). The nature of rape places. Journal of Environmental Psychology, 50, 97-107.

Clarke, J., Heinonen, J., \& Ottelin, J. (2017). Emissions in a decarbonised economy? Global lessons from a carbon footprint analysis of Iceland. Journal of Cleaner Production, 166, 1175-1186.

Cohen, M. J. (2016). The future of consumer society: Prospects for sustainability in the new economy. Oxford: Oxford University Press.

Collier, P., \& Venables, A. J. (2018). Who gets the urban surplus? Journal of Economic Geography, 18(3), 523-538.

Craig, M. P. A. (2017). Ecological political economyand the socio-ecological crisis. Basingstoke: Palgrave Macmillan.

Curtis, C., \& Scheurer, J. (2010). Planning for sustainable accessibility: Developing tools to aid discussion and decision-making. Progress in Planning, 74(2), 53-106.

Curtius, H. C., Hille, S. L., Berger, C., Hahnel, U. J. J., \& Wüstenhagen, R. (2018). Shotgun or snowball approach? Accelerating the diffusion of rooftop solar photovoltaics through peer effects and social norms. Energy Policy, 118, 596-602.

Czepkiewicz, M., Heinonen, J., \& Otellin, J. (2018). Why do urbanites travel more than do others? A review of associations between urban form and longdistance leisure travel. Environmental Research Letters, 13(7), art. 073001.

Czepkiewicz, M., Ottelin, J., Ala-Mantila, S., Heinonen, J., Hasanzadeh, K., \& Kyttä, M. (2018). Urban structural and socioeconomic effects on local, national and international travel patterns and greenhouse gas emissions of young adults. Journal of Transport Geography, 68, 130-141.

del Mar Martínez-Bravo, M., Martínez-del-Río, J., \& Antolín-López, R. (2019). Trade-offs among urban sustainability, pollution and livability in European cities. Journal of Cleaner Production, 224, 651-660.

Dikeç, M. (2001). Justice and the spatial imagination. Environment and Planning $A, 33(10)$, 1785-1805.

Ding, C., Cao, X., \& Næss, P. (2018). Applying gradient boosting decision trees to examine non-linear effects of the built environment on driving distance in Oslo. Transportation Research Part A: Policy and Practice, 110, 107-117.

Dooling, S. (2009). Ecological gentrification: A research agenda exploring justice in the city. International Journal of Urban and Regional Research, 33(3), 621-639.

Duany, A., Plater-Zyberk, E., \& Speck, J. (2001). Suburban nation: The rise of sprawl and the decline of the American dream. New York: North Point Press.

Ellis, L., Farrington, D. P., \& Hoskin, A. W. (2019). Handbook of crime correlates (2nd ed.). London: Academic Press.

Ewing, R., \& Cervero, R. (2010). Travel and the built environment: A metaanalysis. Journal of the American Planning Association, 76(3), 265-294. 
Ewing, R., \& Hamidi, S. (2015). Compactness versus sprawl: A review of recent evidence from the United States. Journal of Planning Literature, 30(4), 413432.

Francart, N., Malmqvist, T., \& Hagbert, P. (2018). Climate target fulfilment in scenarios for a sustainable Swedish built environment beyond growth. Futures: The Journal of Policy Planning and Futures Studies, 98, 1-18.

Freeman, L. (2001). The effects of sprawl on neighborhood social ties. Journal of the American Planning Association, 67(1), 69-77.

Font Vivanco, D., Kamp, R., \& van der Voet, E. (2016). How to deal with the rebound effect? A policy-oriented approach. Energy Policy, 94, 114-125.

Forbes. (2019). Airbnb, Snapgoods and 12 more pioneers of the 'share economy'. Forbes n.d. [online]. URL https://www.forbes.com/pictures/eeji45 emgkh/airbnb-snapgoods-and-12-more-pioneers-of-the-share-economy/\# $71778 \mathrm{e} 5 \mathrm{a} 52 \mathrm{cf}$. Accessed 4 October 2019.

Frick, S. A., \& Rodríguez-Pose, A. (2018). Big or small cities? On city size and economic growth. Growth and Change, 49(1), 4-32.

Ghertner, D. A. (2015). Why gentrification theory fails in 'much of the world'. City, 19(4), 552-563.

Glaeser, E. (2011). Triumph of the city: How our greatest invention makes us richer, smarter, greener, healthier, and happier. Harmondsworth: Penguin.

Glaeser, E. L., \& Sacerdote, B. (1999). Why is there more crime in cities? Journal of Political Economy, 107(6), 225-258.

Gordon, P., \& Richardson, H. W. (1997). Are compact cities a desirable planning goal? Journal of the American Planning Association, 64(1), 95-106.

Gössling, S. (2016). Urban transport justice. Journal of Transport Geography, 54, $1-9$.

Gould, K. A., \& Lewis, T. L. (2017). Green gentrification: Urban sustainability and the struggle for environmental justice. New York: Routledge.

Graziano, M., \& Gillingham, K. (2015). Spatial patterns of solar photovoltaic system adoption: The influence of neighbors and the built environment. Journal of Economic Geography, 15(4), 815-839.

Gyourko, J., \& Saiz, A. (2004). Reinvestment in the housing stock: The role of construction costs and the supply side. Journal of Urban Economics, 55(2), $238-256$.

Haila, A. (2016). Urban land rent: Singapore as a property state. Chichester: Wiley.

Hall, P. (2001). Sustainable cities or town cramming? In A. Layard, S. Davoudi, \& S. Batty (Eds.), Planning for a sustainable future (pp. 101-114). London: Spon.

Haugneland, P., \& Hauge, E. (2014). Norwegian electric car user experiences 2014. Oslo: Norwegian Electric Vehicle Association. 
Heinen, E. (2016). Identity and travel behaviour: A cross-sectional study on commute mode choice and intention to change. Transportation Research Part F: Traffic Psychology and Behaviour, 43, 238-253.

Hendriksz, V. (2015). Filippa K lets shoppers 'lease the look'. Fashion News, 31 August [online]. URL https://fashionunited.uk/news/fashion/filippa-k-letsshopper-lease-the-look/2015083117512. Accessed 4 October 2019.

Holden, E. (2004). Ecological footprints and sustainable urban form. Journal of Housing and the Built Environment, 19(1), 91-109.

Holden, E., \& Norland, I. T. (2005). Three challenges for the compact city as a sustainable urban form: Household consumption of energy and transport in eight residential areas in the Greater Oslo Region. Urban Studies, 42(12), 2145-2166.

Holden, E., Gilpin, G., \& Banister, D. (2019). Sustainable mobility at thirty. Sustainability, 11(7), art. 1965.

Horner, N. C., Shehabi, A., \& Azevedo, I. L. (2016). Known unknowns: Indirect energy effects of information and communication technology. Environmental Research Letters, 11(10), art. 103001.

James, P. (2015). Urban sustainability in theory and practice: Circles of sustainability. London: Routledge.

Jones, C., \& Kammen, D. M. (2014). Spatial distribution of U.S. household carbon footprints reveals suburbanization undermines greenhouse gas benefits of urban population density. Environmental Science and Technology, 48(2): 895-902.

Kaaronen, R. O. (2017). Affording sustainability: Adopting a theory of affordances as a guiding heuristic for environmental policy. Frontiers in Psychology, 8 , art. 1974.

Korpi, M. (2008). Does size of local labour markets affect wage inequality? A rank-size rule of income distribution. Journal of Economic Geography, 8(2), 211-237.

Krueger, R. (2017). Sustainability. In M. Jayne \& K. Ward (Eds.), Urban theory: New critical perspectives (pp. 289-301). Abingdon: Routledge.

Kusno, A. (2013). After the new order: Space, politics, and Jakarta. Honolulu, HI: University of Hawai'i Press.

Kwan, M.-P., Murray, A. T., O'Kelly, M. E., \& Tiefelsdorf, M. (2003). Recent advances in accessibility research: Representation, methodology and applications. Journal of Geographical Systems, 5(1), 129-138.

Larsen, H. N., \& Hertwich, E. G. (2009). The case for consumption-based accounting of greenhouse gas emissions to promote local climate action. Environmental Science and Policy, 12(7), 791-798.

Laurenti, R., Singh, J., Sinha, R., Potting, J., \& Frostell, B. (2016). Unintended environmental consequences of improvement actions: A qualitative analysis 
of systems' structure and behavior. System Research and Behavioral Science, 33(3), 381-399.

Lee, J. W. Y., \& Tang, W.-S. (2017). The hegemony of the real estate industry: Redevelopment of 'Government/Institution or Community' (G/IC) land in Hong Kong. Urban Studies, 54(15), 3403-3422.

Lerpold, L., \& Sjöberg, Ö. (2021a). Urban advantage? Sustainable consumption and ontological cityism across the urban hierarchy. In R. Bali Swain \& S. Sweet (Eds.), Sustainable consumption and production, Volume 1: Challenges and development. London: Palgrave Macmillan.

Lerpold, L., \& Sjöberg, Ö. (2021b). Tourism as (un)sustainable production and consumption. In R. Bali Swain \& S. Sweet (Eds.), Sustainable consumption and production, Volume 2: Circular economy and beyond. London: Palgrave Macmillan.

Lin, J.-J., \& Yang, A.-T. (2006). Does the compact-city paradigm foster sustainability? An empirical study in Taiwan. Environment and Planning B: Planning and Design, 33(3), 365-380.

Makido, Y., Dhakal, S., \& Yamagata, Y. (2012). Relationship between urban form and $\mathrm{CO}_{2}$ emissions: Evidence from fifty Japanese cities. Urban Climate, 2, 55-67.

Maloutas, T. (2011). Contextual diversity in gentrification research. Critical Sociology, 38(1), 33-48.

Manski, C. F. (1993). Identification of endogenous social effects: The reflection problem. Review of Economics and Statistics, 60(3), 531-542.

Marcus, L. (2016). Cognitive affordances in sustainable urbanism: Contributions of space syntax and spatial cognition. Journal of Urban Design, 21(4), 439542 .

Martén, L., Hainmueller, J., \& Hangartner, D. (2019). Ethnic networks can foster the economic integration of refugees. Proceedings of the National Academy of Sciences of the United States of America, 116(33), 16280-16285.

Martens, K. (2012). Justice in transport as justice in accessibility: Applying Walzer's 'Spheres of Justice' to the transport sector. Transportation, 39(6), 1035-1053.

Maxwell, D., Owen, P., McAndrew, L., Muehmel, K., \& Neubauer, A. (2011). Addressing the rebound effect. A report for the European Commission DG Environment. Global View Sustainability Services (GVSS) Ltd 26 April.

Mehan, A. (2017). An integrated model of achieving social sustainability in urban context through Theory of Affordance. Procedia Engineering, 198, 17-25.

MoF. (2016). Strategy for sustainable consumption. Stockholm: Ministry of Finance, October.

Möller, J., Daschkovska, K., \& Bogaschewsky, R. (2019). Sustainable city logistics: Rebound effects from self-driving vehicles. In C. Jahn, W. Kersten, \& C. M. Ringle (Eds.), Digital transformation in maritime and city logistics 
(pp. 299-337). Proceedings of the Hamburg International Conference of Logistics 28. Berlin: epubli.

Næss, P. (2006). Urban structure matters: Residential location, car dependence and travel behaviour. Abingdon: Routledge.

Næss, P. (2012). Urban form and travel behaviour: Experience from a Nordic context. Journal of Transport and Land Use, 5(2), 21-45.

Næss, P., Saglie, I.-L., \& Richardson, T. (2020). Urban sustainability: Is densification sufficient? European Planning Studies, 28(1), 146-165.

Neuman, M. (2005). The compact city fallacy. Journal of Planning Education and Research, 25(1), 11-26.

Nielsen, J., \& Farrelly, M. A. (2019). Conceptualising the built environment to inform sustainable urban transitions. Environmental Innovation and Societal Transitions, 33, 231-248.

Nikel, D. (2019). Electric cars: Why little Norway leads the world in EV usage. Forbes, 18 June [online]. URL https://www.forbes.com/sites/davidnikel/ 2019/06/18/electric-cars-why-little-norway-leads-the-world-in-ev-usage/\# 2022724dl3e3. Accessed 4 October 2019.

Nikulina, V., Simon, D., Ny, H., \& Baumann, H. (2019). Context-adapted urban planning for rapid transitioning of personal mobility towards sustainability: A systematic literature review. Sustainability, 11(4), art. 1007.

Peters, G. P., Minx, J. C., Weber, C. L., \& Edenhofer, O. (2011). Growth in emission transfers via international trade from 1990 to 2008. Proceedings of the National Academy of Sciences of United States of America, 108(1), 89038908.

Palm, A. (2017). Peer effects in residential solar photovoltaics adoption: A mixed methods study of Swedish users. Energy Research and Social Science, 26, 1-10.

Plaut, P., \& Plaut, S. (2010). Decisions to renovate and to move. Journal of Real Estate Research, 32(4), 461-484.

Putnam, R. D. (1993). Making democracy work: Civic traditions in modern Italy. Princeton, NJ: Princeton University Press.

Reuters. (2019). E-scooters put Swedish startup on road to positive cashflow. Voice of America, 8 July [online]. URL https://www.voanews.com/ economy-business/e-scooters-put-swedish-startup-road-positive-cashflow. Accessed 4 October 2019.

Revi, A., Satterthwaite, D. E., Aragón-Durand, F., Corfee-Morlot, J., Kiunsi, R. B. R., Pelling, M., ... Solecki, W. 2015. Urban areas. In C. B. Field, V. R. Barros, D. J. Dokken, K. J., Mach, M. D. Mastrandrea, T. E. Bilir, ... L. L. White (Eds), Climate change 2014-Impacts, adaptation, and vulnerability. Part A: Global and sectoral aspects. Contribution of Working Group II to the Fifth Assessment Report of the Intergovernmental Panel on Climate Change (pp. 535-612). New York: Cambridge University Press. 
Roos, S. (2017). Advancing life cycle assessment of textile products to include textile chemicals: Inventory data and toxicity impact assessment. Gothenburg: Chalmers University of Technology.

Rose, D., Bodor, J. N., Swalm, C. M., Rice, J. C., Farley, T. A. \& Hutchinson, P. L. (2009). Deserts in New Orleans? Illustrations of urban food access and implications for policy. Paper prepared for University of Michigan National Poverty Center/USDA Economic Research Service Research, Understanding the Economic Concepts and Characteristics of Food Access, February.

Sen, A. (1984). The living standard. Oxford Economic Papers, 36(Supplement), 74-90.

Shatkin, G. (2017). Cities for profit: The real estate turn in Asia's urban politics. Ithaca, NY: Cornell University Press.

Shaw, H. J. (2006). Food deserts: Towards the development of a classification. Geografiska Annaler: Series B, Human Geography, 88(2), 231-247.

Shirazi, M. R., \& Keivani, R. (2017). Critical reflections on the theory and practice of social sustainability in the built environment-A meta-analysis. Local Environment, 22(12), 1526-1545.

Susser, I. (1996). The construction of poverty and homelessness in US cities. Annual Review of Anthropology, 25, 411-435.

Tang, W.-S. (2014). Where Lefebvre meets the East: Urbanization in Hong Kong. In L. Stanek, C. Schmid \& Á. Moravánszky (Eds.), Urban revolution now. Henri Lefebvre in social research and architecture (pp. 71-91). Farnham: Ashgate.

Tang, W.-S. (2017). Beyond gentrification: Hegemonic redevelopment in Hong Kong. International Journal of Urban and Regional Research, 41(3), 487499.

Tang, W.-S. (2019). Town-country relations in China: Back to basics. Eurasian Geography and Economics, 60(4), 455-485.

Tang, W.-S., Lee, J. W. Y., Hui, T. W., \& Yip, M. K. C. (2019). The "urban density" question in Hong Kong: From absolute space to social processes. City, Culture and Society, 17, 46-53.

Underwood, A., \& Fremstad, A. (2018). Does sharing backfire? A decomposition of household and urban economies in $\mathrm{CO}_{2}$ emissions. Energy Policy, 123, 404-413.

UN-Habitat. (2014). A new strategy of sustainable neighbourhood planning: Five principles (Discussion Note 3). Urban Planning and Design Branch, United Nations Human Settlements Programme, Nairobi.

Vallence, S., Perkins, H. C., \& Dixon, J. E. (2011). What is social sustainability? A clarification of concepts. Geoforum, 42(3), 342-348.

Verboven, H., \& Vanherck, L. (2016). The sustainability paradox of the sharing economy. UmweltWirtschaftsForum, 24(4), 303-314. 
Waters, J. (2016). Accessible cities: From urban density to multidimensional accessibility. In D. Simon (Ed.), Rethinking sustainable cities: Accessible, green and fair (pp. 11-59). Bristol: Policy Press.

Wessel, T. (2009). Does diversity in urban space enhance intergroup contact and tolerance? Geografiska Annaler: Series B, Human Geography, 91(1), 5-17.

Wheeler, S. M. (2013). Planning for sustainability: Creating livable, equitable, and ecological communities (2nd ed.). Abingdon: Routledge.

Wilson, J. (1985). Thinking about crime. New York: Random House.

Wolch, J., Dear, M., \& Akita, A. (1988). Explaining homelessness. Journal of American Planning Association, 54(4), 443-453.

Wong, K. P. (2019). Territorially-nested urbanization in China-The case of Dongguan. Eurasian Geography and Economics, 60(4), 486-509.

Wu, X., Tao, T., Cao, J., Fan, Y., \& Ramaswami, A. (2019). Examining threshold effects of built environment elements on travel-related carbon-dioxide emissions. Transportation Research Part D: Transport and Environment, 75, $1-12$.

Xie, Y., \& Gough, M. (2011). Ethnic enclaves and the earnings of immigrants. Demography, 48(4), 1293-1315.

Yang, W., Wang, W., \& Ouyang, S. (2019). The influencing factors and spatial spillover effects of $\mathrm{CO}_{2}$ emissions from transportation in China. Science of the Total Environment, 696, art. 133900.

Open Access This chapter is licensed under the terms of the Creative Commons Attribution 4.0 International License (http://creativecommons.org/licenses/ by $/ 4.0 /$ ), which permits use, sharing, adaptation, distribution and reproduction in any medium or format, as long as you give appropriate credit to the original author(s) and the source, provide a link to the Creative Commons licence and indicate if changes were made.

The images or other third party material in this chapter are included in the chapter's Creative Commons licence, unless indicated otherwise in a credit line to the material. If material is not included in the chapter's Creative Commons licence and your intended use is not permitted by statutory regulation or exceeds the permitted use, you will need to obtain permission directly from the copyright holder.

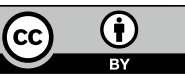

